\title{
Two Functions of the Imagination IN Greene's Aesthetic Educational Theory
}

\section{James Stillwaggon}

In Art as Experience, Dewey claims that “'imagination' shares with 'beauty' the doubtful honor of being the chief theme in esthetic writings of enthusiastic ignorance. More perhaps than any other phase of the human contribution, it has been treated as a special and self-contained faculty, differing from others in possession of mysterious potencies." Despite this "doubtful honor," or as some might claim, because of it, imagination seems to have become a matter of unquestionable value in educational rhetoric over the last half-century. ${ }^{2}$ This value is doubtless due in part to the immeasurable influence of Maxine Greene's understanding of aesthetic education on broad swaths of educational thought. ${ }^{3}$ Yet Greene's influence can itself be traced to its place in a zeitgeist that comprises at least two other important trends related to the power of the image, providing her aesthetic-social theory with a fertile environment in which to flourish. One of these trends is an emphasis on including and celebrating diversity as a means to a vision of society that has yet to be realized or codified and therefore necessitates the imaginative breaks that Greene's ideas require. After the Brown v. Board Supreme Court decision, America came to see education as a scene of practical application in the Civil Rights movement-a place where the difficult task of realizing the democratic promise inherent in America's laws might be undertaken without failing under the weight of deeply embedded social norms. The classroom has become the ever-open site where progressive idealism might claim children's imaginations on behalf of a radically changing picture of what counts as human.

The second of these trends is a repeated skepticism about the discursive workings of power and a shift in emphasis in some scholarly work on education to nondiscursive elements of human experience. This backlash against both structuralist social sciences and analytic philosophy drives educational studies toward a greater interest in existential experience, the extra-linguistic, affect, idiocy, suffering, and the abject. Within this trend, the irrational, unthought, unrepresented aspects of the human being operate on two distinct levels. On the one hand, educational theorists draw our attention to those elements of our shared humanity that our discursive practices obscure and marginalize in order to exclude what cannot be explained without putting the discourse itself into question. On the other hand, the 
marginalized, extra-discursive position serves as a novel, if contingent, perspective from which to launch critical attacks upon the status quo.

Joined with these allied trends, imagination can be seen as a means to liberate subjectivity from the particularity of its constructed, discursive nature through the presence of an "other" who offers the possibility of change for both the individual subject and the discourses to which she is subject. If the goal is progressive growth, achievable only through the ritual breaking of those beliefs and values that shape the way we see the world, imagination seems to provide the means, allowing us to see the limits of our existing discourses and the possibilities inherent therein. While this story of progressive growth and the possibility of social progress by means of critical breaks with the past is by far the greater theme in Greene's work, I argue here that her writings also maintain a second, less developed or perhaps simply less influential theme, namely, that of imagination as an integrating and coordinating action upon a diversely populated environment and a disjointed feeling of selfhood.

The problem with this second concept of imagination in Greene's work is that, if it is taken together with the first, these two ideas provide a seemingly paradoxical definition of imagination, particularly in its educational applications. In short, this compound definition would seem to state that imagination is both that which disrupts and undermines my established sense of selfhood by presenting incomprehensible alternatives and that which provides the sense of narrative continuity essential for establishing a stable sense of selfhood. By acknowledging the first, more influential theme that aligns imagination, critical thought, and social change, the aim of this essay is to make sense of the second theme, that of imagination as an integrating and coordinating aspect of human experience. By giving our attention to this second theme, I argue neither that the apparent contradiction between the two themes falls away nor that we can find some comfortable middle ground between the two. Instead, I argue that the characteristics allowing imagination to operate in both of these contradictory directions also undergirds educational scholars' contemporary faith in aesthetic education as that which has the power to change both individuals and society in a way that discursive practices cannot, precisely because imagination's role in coordinating and shoring up our ideas of selfhood means that images can also threaten that same sense of selfhood in ways that words cannot. Through Plato's critique of poetic images as a moral curriculum, Lacan's theorization of the mirror stage, and through these authors' overlapping theories of the origins of desire in the human subject through the power of the imaginary, I consider how the image serves as both the subject's entry point into the world of human community and as the means by which one's relationship to discursive norms might be overcome, or at least upset. On the one hand, unfamiliar, yet compelling and seemingly complete images may provide the subject with new desires of what it wants to be. On the other hand, disturbingly familiar images may suggest to the subject the untenability of its relationship to the world. 


\section{INCOMPLETENESS, IMAGINATION, AND FREEDOM}

In the last half century, educational theorists have adopted a critical stance and taken on a task of unveiling the economies of power that drive schooling, despite the themes of hope and goodwill typically invoked in educational rhetoric. Citing discursive power as one of the means by which oppressive power in schools is maintained, many theorists look to extra-linguistic sources-from the somatic and violent to the affective and artistic-upon which resistance or rebellion against oppressive educational discourses might gain a foothold. In her 1995 collection of essays Releasing the Imagination, Maxine Greene aligns herself with the radical educational critique of her time by telling of her "feeling of loss, after civil rights, of what we are doing."' Like Arendt's example of the partisan fighter who returns to peaceful times to find his purpose in the world lost, and uneasy with postmodernism's failure to produce meaningful political courses of action, Greene's words reflect a fear that education will be turned over to the functionaries and clerks of the world, who will keep account of schooling processes without ever questioning what it is that we do when we teach, and who may drive great teachers away from the practice altogether while preventing the minds of future generations from achieving the "wide awakeness" that characterizes her ethical perspective. A similar formulation of the opposition between imagination and discursive power appears in The Dialectic of Freedom: "A concern for the critical and imaginative, for the opening of new ways of 'looking at things,' is wholly at odds with the technicist and behaviorist emphases we still find in American schools. It represents a challenge, not yet met, to the hollow formulations, the mystifications so characteristic of our time." In aligning her views on imagination with a critical social philosophy, Greene responds to a more conservative interpretation of the received wisdom of schooling as conscious social reproduction with a flat rejection: "it is simply not enough for us to reproduce the way things are." Instead, she argues, according to a rhetoric that has become commonly accepted among educational theorists, that schools must also be places where radical difference is possible, and where social change begins in the ability to see things as if they could be otherwise. Within this vision of schools as sites of social change, imagination serves as the human faculty capable of contending with the unfamiliar that might offer a more democratic alternative to the status quo. As Greene quotes Sartre, our ability to imagine another, better state of affairs, or being-as-otherwise, provides the push away from the social woes we have come to take for granted: "it is on the day that we can conceive of a different state of affairs that a new light falls on our troubles and our suffering and that we decide that these are unbearable."

Greene's idea of imagination as a function of human freedom, as that which opens human beings to a broader range of possibilities, is expressed in her title Releasing the Imagination, in which imagination is invoked as a bird or other wild 
creature that might be freed from its captivity within oppressive structures of social constraint and narrow thinking, and take on its natural expression and activity in the spiritual production of the new. Her understanding of the work of schools seems directly tied to this goal of release: "teaching and learning are matters of breaking through barriers-of expectation, of boredom, of predefinition," and she suggests that the problems commonly associated with schools, such as "apathy and indifference are likely to give way as images of what might be arise." ${ }^{\prime}$

Greene's influence on educational theory presents itself in our often unacknowledged assumption that schools promote greater freedom and democracy when they inspire students to imaginatively move beyond their existing understandings of the world. Recently, under the pressing need to understand greater cultural diversity in public schools, this venturing out into the unknown has been given voice in the question of how the subject is challenged by and might learn through its interactions with otherness. This understanding of imagination dislocates the agency of change from the teacher or student as imagining subject or image maker to a radical form of otherness that cannot be defined or even anticipated in advance of its arrival. In an essay that highlights the subject's dependence on the unknown for its capacity to deliver a new experience, Claudia Ruitenberg quotes John Caputo on the subject of radical otherness: "how to prepare for one whom the only adequate preparation is to confess that we cannot be prepared for what is coming?" Caputo's question, and Ruitenberg's analysis that follows it, suggest a great degree of stability in the subject who is willing to allow herself to be destabilized, who can feel secure despite the discomfort of a "hot potato in our mouth"-a metaphor Ruitenberg uses to illustrate images of difference that cannot be reduced to variations on sameness. ${ }^{10}$

The fixed, stable worldview destabilized in Ruitenberg's account of the educational subject, whose capacity for imagining the new and experiencing some sort of freedom has been closed in upon itself, delivers only variations on existing themes, and requires the intrusion of the other for its continued growth and renewal. But precisely because the subject of this disruptive education seems-as in Greene's work that informs it-already formed by its experiences, the role of the image as a liberator from the "cotton-wool" of everyday experience begs the question of how the subject becomes invested in that series of fixed images from which its education later provides extrication. As the ideals of class, cultural, or national identity that Greene describes as limitations to freedom originate from the social rather than the natural realm, the subject's entanglement in these ideals must also originate from its education in a curriculum of images.

Greene's account of the education of imagination would seem narrowly capricious if it proceeded by employing one set of images deemed "emancipatory" to counteract the negative characteristics of another collection of images deemed "oppressive." But her treatment of imagination suggests that she recognizes the 
paradoxical possibilities that arise out of the inherently ambivalent nature of images. While the major theme of Greene's essays on imagination undoubtedly follows the trend of imagination as a key to change and reform discussed above, a second theme that runs throughout her work concerns the relationship between identity and the image and suggests that imagination grounds and extends human identity over time rather than fracturing the subject in an endless flow of difference.

Greene provides a connection between image and identity from the very outset of Releasing the Imagination, whereby she connects the role of imagination with Charles Taylor's idea of a quest as an organizing principle for a human life. Greene closes this first essay with a similar statement regarding the significance of some stable sense of self, namely, that as humans our " fundamental anxiety' is that we will pass through the world and leave no mark." "11 These refrains establish an idea of imagination that releases the beholder from the constraints of the status quo only at the cost of subscribing to yet another way of seeing the world that organizes the subject's purposes as an effect of its power of presentation.

These two seemingly oppositional functions of the imagination-integration and disintegration - run throughout Greene's work, and, perhaps due to her influence in educational research, the ambivalent character of the image is taken for granted in much of educational thought. Nor is the seemingly contradictory character of the image limited to its treatment in pedagogical theory. Greene quotes two theorists on the imagination whose work seems to demonstrate the same conflict in the role of imagination without highlighting that conflict as a problem. From Mary Warnock, Greene quotes the following: "[Imagination] is the way we render the world familiar and therefore manageable. At a different level, and sporadically, we may also use it to render our experience unfamiliar and mysterious. If, below the level of consciousness, our imagination is at work tidying up the chaos of sense experience, at a different level it may, as it were, untidy it again."12 And from G. B. Madison, "It is through the imagination, the realm of pure possibility that we freely make ourselves to be who or what we are, that we creatively and imaginatively become who we are, while in the process of preserving the freedom and possibility to be yet otherwise than what we have become and merely are." ${ }^{13}$ While Madison seems unaware of the contradiction, allowing imagination to do anything by tying its meaning down to nothing, Warnock seems completely aware of the contradictory nature of imagination, discriminating between its opposed functions by placing them "at a different level" from one another. This differentiation by level seems to be a step in the right direction, suggesting that human subjects might possess more than one kind of imagination or image making function, but Warnock does not pursue these alternate functions separately. In order to follow the differentiation suggested by Warnock, and to better understand how the imagination, as a single faculty, is capable of two seemingly opposed functions, in the next section I turn to 
one of the most enduring frameworks for understanding the relationship between images, education, and human freedom, namely, Plato's Republic.

\section{IMAGINATION AS THE FOUNDATION OF IDENTITY}

Centuries of scholarship have misinterpreted Plato's Republic, Books II and X, as an absolute statement of Plato's negative views regarding poets and poetry, disregarding the hypothetical context in which Socrates's censorship and banishment of poetry and the poets takes place. While a thorough analysis and refutation of these interpretations are beyond the scope of this paper, it should suffice to mention some of the arguments that have been raised critiquing any simple account of the ancient feud between philosophy and poetry: that Plato himself was a poet, writing in a dialogic style of narrative particular to poets in his time; that Plato gives some poets of his time some of the most eloquent and memorable lines in his work and quotes the poets who preceded him with regularity and authority; that the noble lie upon which Plato establishes his hypothetical city consists just as much of poetic images as the works of Homer and Hesiod it replaces; and, perhaps most importantly with respect to the most damaging criticism of Plato's thoughts on the poets, that in the Republic Plato is not prescribing an actual role for poets in a real city, but is demonstrating, through a complex, poetic metaphor, the possibility of achieving Adeimantus's and Glaucon's challenge: justice without the promise of reward or the threat of punishment.

The most significant feature of Plato's critique of the poets in Book II of the Republic is that, in confronting particular poetic narratives from Homer and Hesiod as guides for the moral upbringing of the guardian class, Plato simultaneously recognizes the power and the threat of poetic images in grounding the moral education of the guardian class and, through the myth of the metals, in organizing the imagined state itself (375a-377e).${ }^{14}$ The threat that the poets pose to the state is not that their work is inherently flawed or necessarily corrupt, but that the poets fail to understand the generative character of the images they produce in shaping the morals of the young - a theme that is carried across Plato's writings. According to the Ion, the poets understand neither their own processes of creation, nor the poetic effect that their creations might have on others, but are merely the passive media through which the divine speaks (533d-534c). In the Meno, Plato emphasizes the importance of "tethering" divinely revealed truths, such as those the poets reveal, through critical reasoning, so that their effects in the world will not be misplaced and produce effects that contradict the divine will (97d-98b). In the Symposium, Plato elaborates on the poets' inability to exercise the critical capacity that would make their art useful, demonstrating the poets' failure to understand the relationship between the images they produce and the desires that these images, in turn, produce in their audience (194c, 205b). 
Plato's construction of a moral and political curriculum of images in the Republic challenges us to understand the human subject's relation to the images in which its identity is invested, the relationship between the imaginary and the subject's desire to become like those images that attract through their beauty, perfection, or sublimity. In other words, if the image presents itself as a wholeness which the human subject finds itself lacking and thereby inspires desire in the beholder, then why do some images of completeness attract and others not? What is the basis for the subject's relationship to the image? Plato answers these questions in the context of the Republic by describing children's souls as similar to wet clay insofar as they receive whatever imprint is pressed upon them (377b), but only begins to provide a more complex account of the malleability of the human soul in the Symposium. In the latter text, in a play of completeness and incompleteness, Diotima describes poros (resource) and penia (poverty), as the parents of Eros. According to Diotima's genealogy, desire emerges from the human subject's painful awareness of her incompleteness or lack when faced with an image of wholeness (203b-d). Illustrated through Socrates's brief dialogue with Agathon at the center of the text (199c-201d) and Alcibiades's confession of love at the close of the text (215a-222c), the human subject does not experience desire on its own, but only as an effect of its desired object: an image of completeness in relation to which the subject feels her own lack.

For Plato, this means that the desiring subject's identity is not entirely her own, but is experienced as an internalized negative of the image to which it is tied. While on the one hand desire awakens the subject to a more fundamental incompleteness that marks human beings, on the other, desire is always experienced as a specific lack and in relation to a particular image of completeness.

The close relationship between desire and imagination in Plato returns throughout the history of Western philosophy as a theme of human self-creation, but it receives some of its most explicit treatment in the psychoanalytic work of Jacques Lacan. In an early essay, "The Mirror Stage as Formative of the Function of the I as Revealed in Psychoanalytic Experience," Lacan describes the subject's relation to the image by taking a borrowed discovery, that of the child's recognition of its own reflection in the mirror from the age of six months, and positing this "mirror stage" as fundamental to the child's "formation of the $I$," as a human subject aware of its agency in a shared world. ${ }^{15}$ Unlike a developmental notion of a stage, the mirror stage is not a point that the subject passes through and completes, but serves instead as the subject's initiation to the world of the imaginarythe world conceived in terms of images-in which the subject's identity remains invested throughout its life and outside of which it cannot make sense of itself or the world around it.

According to Lacan, the human infant initially experiences a series of disconnected, disorganized energies and internal as well as external perceptions, over 


\section{J. StillwagGon}

which it has neither control nor any organizing principle of a body or a bounded self that would allow it to understand these impulses and sensations as its own. The founding moment for a developing child's experience of itself as a single entitybounded, individuated, and agentic-occurs in its first recognition that these sensations all belong to a single body. In the case of the infant's response to its own image, the mirror offers a promise of unity and integration-a "fictional direction" that contradicts the child's fragmented experiences of herself, observed in the infant's response in what Lacan calls "a flutter of jubilant activity," a rush of physical excitement that, from the adult observer's standpoint, we might misunderstand as an expression or externalization of a joy that the child experiences internally in knowing itself as a visually perceptible, bounded whole. ${ }^{16}$

According to Lacan's schema, this notion of expressing an internal, preexisting feeling of the self is unfounded, as the child does not yet have a sense of itself as something recognizable. Instead of the outward movement of internally experienced emotion, Lacan posits the child's recognition of itself in the mirror as a moment of initiation into the imaginary, in which the child's internal sense of being a self, and the emotions that go with it, are impressed upon it by the visual image received from the mirror. "The mirror stage is a drama whose internal thrust is precipitated from insufficiency to anticipation-and which manufactures for the subject, caught up in the lure of spatial identification, the succession of phantasies that extends from a fragmented body-image to a form of its totality that I shall call orthopaedic - and lastly, to the assumption of the armour of an alienating identity, which will mark with its rigid structure the subject's entire mental development."17 Through this first introduction and through subsequent experiences, the child comes to understand and experience itself through the mirror image's promise of a unified and individuated being rather than merely an extension of its parent or as a fragmented body of uncontrollable movements and energies.

In contrast to those theorists of imagination in education who emphasize the place of the image in changing the subject through oppressive or liberatory ideals, Lacan's account of the mirror stage suggests that participation in the imaginary produces the identity of the child in a manner that is neither oppressive nor liberatory, but constitutive. Just as Lacan's idea of the fragmented body has its parallel in Greene's recognition of our fundamental anxiety that in the end we will leave no mark on the world, the narrative endeavors in which Greene recognizes human attempts to overcome their fundamental anxiety can be seen as the work of employing the organizing power of the mirror image in providing the fantasy of an integrated self.

\section{From Self-Integration to Social Change}

If the imaginary founds and gives order to the subject through its projection of itself as an integrated, if incomplete, whole, we might still inquire about those theories of imagination in education in which the image appears as a catalyst of change. In order 
to make sense of these two functions together, it is first necessary to understand how the image serves as a medium through which the subject comes to relate to others.

Through its initial recognition of its own potential as an agentic entity, Lacan claims that the child comes to view others as analogues of its own image and as fulfillments of the mirror's promise of an integrated selfhood. Recalling this same impulse of integrating and seeing order in the world in relation to oneself, Greene provides a poetic reflection on everyday experience: "One abruptly perceives willow trees, 'all plumy and soft green and purple against the blue' or one sees a connection between an apple tree and someone's suicide, between a children's quarrel and the darkness of the earth. At such times, one may be moved to 'put the severed parts together, to impose some order or some meaning on it all."'18 Establishing an initial, prediscursive order from an underlying confusion, the world of images also establishes relations with the world as it distinguishes the subject from its surroundings. Having ordered her own "severed parts" into a whole with the potential for meaning, the subject equally authorizes herself to order the world in terms of her own experience of it. According to Greene's quotation of Wallace Stevens, "[The imagination] is part of our security. It enables us to live our own lives. We have it because we do not have enough without it. This may not be true as to each one of us, for certainly there are those for whom reality and reason are enough. It is true enough of the race." ${ }^{\prime 19}$ Stevens's quotation makes an important jump from the individual to the "race" and, in bringing imagination to the level of the social, provides the context wherein we may restate our question about the relationship between the two themes in Greene's theory of imagination. If one set of images provides us with the sense of continuity and integrity necessary to pick up the task of our lives every day, how could we be willing to pick up another set of images tomorrow and completely reorient ourselves to the world? How can imagination do the work of social change if this involves undoing the coherence it helps to build?

Studies such as Deborah Britzman's "Cultural Myths in the Making of Teachers" and Mick Markham's "Through the Looking Glass"-both of which focus on the power of the imaginary in shaping a teacher's identity-suggest that disrupting longstanding imaginary attachments requires committed and sustained effort and may not be entirely attainable through the work of discourse. The change required by difficult images is so tied to our identity that we are often unable to give up our sustaining imaginary even for compelling reasons. Reasons, after all, are discursive, and often do not move us at the level of the imaginary, in which our attachments are tangentially connected to, and therefore largely immune to, ordinary operations of language. Faced with difficult images that threaten the way we see the world and our place in it, however, our discursive tools of critical analysis and questioning become a powerful means of inoculating ourselves against their subversive potential. Connecting an image to the discursive context that gives it meaning allows the subject to skate on a slippage of signifiers and endlessly detour from herself and the potential for damage experienced in the gaze of an unexpected or unwanted image. 


\section{J. StillwagGon}

The power of alternative images in changing our imaginary commitments connects to what Dewey calls the image's integrity and inevitability. Contrary to the position quoted at the outset of this essay, Dewey seems to give in to the seduction of the imagination, conceding that "all conscious experience has of necessity some degree of imaginative quality," and further claiming that imagination offers "a way of seeing and feeling things as they compose an integral whole.... When old and familiar things are made new in experience, there is imagination. When the new is created, the far and strange become the most natural inevitable things in the world." ${ }^{20}$ The real potential for change to be made through images comes when the integral whole, the picture of one's world that in turn provides an integral sense of self, comes together in a way that implicates the subject inescapably, offering her a realization of her own contingency or, more painfully, her culpability in a fundamentally unjust picture of the world.

Greene is aware of the difficulty at hand in being confronted by new images, and she seems to allow that there may be an effect that is neither wholesale rejection nor what Rorty would call cultural irony: "Aware, then, on some level of the integrity and the coherence of what may seem to us to be a totally alien world in the person of another, we are called upon to use our imaginations to enter into that world, to discover how it looks and feels from the vantage point of the person whose world it is ... the extent to which we grasp another's world depends on our existing ability to make poetic use of our imagination." ${ }^{21}$ While it may be impossible, in any active sense, to imagine the world from another's perspective, the point to which Greene seems to be driving here is that the image of the other, and the very impossibility of seeing through the other's eyes conveyed by that image, may be enough to excite our desires, to disrupt our established sense of selfhood, and to use the extra-linguistic aspects of human experience to reshuffle the world of words as we know it.

In keeping with the decentering and destabilizing function of the imageas-other that Ruitenberg identifies, the theme of identification with the image in Greene's work may be qualified with the understanding that the identity offered by the image is never fully attainable, and serves to draw the subject out of itself rather than providing a solid place to arrive. Following the metaphor that Ruitenberg uses, the image may be experienced like a "hot potato in our mouth:" it may be held, but neither swallowed, digested, nor integrated in the subject's erotic consuming of the other. Reversing that metaphor entirely, perhaps it is not the image or the object but the subject who is swallowed by, and becomes a part of, the world of images, insofar as its identity is invested and attached, held in tension between the various images through which it understands itself and which serve to impel it onward.

\section{Two Functions of the Imagination In History}

The Civil Rights Movement of the 1950s and 1960s made extensive use of photographic and film images that are instantly recalled: the mangled face of Emmett 
Till, the angry crowd following Elizabeth Eckford outside of Little Rock Central High School, police dogs unleashed on Birmingham protesters. Even as these images betray our sense of humanity and safety, they sit safely in a historical narrative of heroic overcoming and remarkable success. Despite their portrayal of horrific scenes, these black and white prints provide a sense of closure through their support of a narrative of political and social progress in America that suggests the hardest and most important battles have already been fought. For students studying the Civil Rights Movement in states outside of the South, the distance is not only temporal but geographical and cultural, reinforcing a commonly held belief about the relative freedom of black people in the North during the time of Jim Crow laws in the South. The shock that these images produce can be experienced at a distance, reinforcing the relative justice of our contemporary social and political arrangements, through questions such as: how could people live in such a way, witnessing the manner in which their fellow human beings suffered at the hands of an unjust and brutal political regime?

While American culture's imaginary relationship to the Civil Rights Movement serves the integrative, identity forming function described in Greene's work, the doubled and paradoxical power of the imagination rests in the fact that similarly brutal images of institutional violence on black bodies, set in a different historical context, may play a role that not only fails to support Americans' positive feelings about their progress toward racial equality but instead, echoing Greene's quotation of Sartre, brings us to the point of realizing that the social and political conditions under which we live are unbearable. The nation's new awareness of the oppression and brutality suffered by black people in America has been brought about largely by the work of eyewitnesses using cellphones as a means to bring objectivity to an otherwise hopelessly fragmented discourse on the connections between poverty, crime, and the policing of black communities in America. As the video footage of Eric Garner's arrest has demonstrated, the significance of eyewitness images has had little to do with their capacity to establish an objective account of events. Instead, in similar fashion to the work of images during the Civil Rights Movement, eyewitness phone camera footage has brought about visceral responses of shame, anger, and moral outrage.

A still from the video footage that captured the shooting of Walter Scott stands out from many of these images because of the simplicity and clarity of its aesthetic as well as the conflict it draws between its setting and the action that takes place within it. The vacant lot in which the scene is set is green and park-like. A large tree in the foreground divides the green field with a dark, uncertain blot, almost allowing the viewer to persist in a feeling of innocence that these must be two separate images. And yet the relation between the two figures on either side of the tree is unmistakable: to the right of the tree, a white man in dark clothes stands, pointing a handgun toward the left side of the image; on the left side of the tree, a 
black man in a green sweatshirt and jeans runs with his shoulders thrust forward and his arms tucked close to his body. Informed by a litany of images from the Lascaux cave paintings and Attic vase motifs to images of the American West captured by Remington and Kane, the image reads unmistakably as a hunting scene, one in which the horror of one person hunting another who flees for his life is depicted in the grainy, somewhat flat medium that we typically use to capture birthdays, school pageants, and other banal elements of our lives.

Given the discussion above, we might imagine that in a century the image of Walter Scott's shooting might serve as a point of historical reflection in a larger narrative of America's growth and change, in the same way that the photograph of Emmett Till's open casket and the story that goes with it have become part of the historical account of the country's struggle toward racial equality. But the advent of this historical, socially integrative function for an image such as that of Walter Scott depends heavily on that image's capacity to disrupt and undo whatever stable self-understanding Americans have allowed themselves through the integrative function of Civil Rights era images, turning our moralizing questions about how people could have lived as witnesses to inhuman oppression into questions about how it is possible to live under such conditions today.

\section{CONCLUSION}

The image, as that inchoate awareness of the world thought to precede clear rational thinking, has served a problematic function in educational thought since Plato's Republic. Images serve as an aesthetic interface with the world, providing us with a palpable and credible sense of their immediacy and incontrovertibility. But precisely due to these claims of presence and self-evidence they may be rendered suspect through discursive functions of reflection or analysis. Plato expresses the urgency of curricular images as a problem of how developing human subjects come to understand themselves in relation to various expressions of human value. As children's souls are like wet clay, taking any imprint that we put upon them while young, and bearing that imprint as the basis of their relation to the world, Plato's Socrates argues that the traditional moral curriculum of epic poetry must be carefully censored in order to meet the pedagogical and political needs of the imagined city he discusses with Glaucon and Adeimantus (377b-e).

Even in this example, Plato demonstrates the inseparability of the two functions of the imagination that have been identified in the present essay as a seemingly paradoxical pair: one to shore up and the other to tear down. In Plato's thought experiment, censorship not only turns a critical, destructive eye toward the work of the past, erasing a cultural history for the sake of a carefully engineered ethics. In Socrates's proposed collection of myths that displaces Homer's and Hesiod's a new poetic purpose is shaped, constituting new forms of subjectivity that would not be possible within the discursive horizon that Socrates's interlocutors took for 
granted. Conversely, the idea of engaging in a critical look at the past, of breaking with the constituting images that have come before us without at least implicitly offering new images of our own, is simply unthinkable. In the absence of any explicitly new founding narrative, the critic herself and the act of unveiling the myths of history become the new images because, at least according to the aesthetic and social philosophies of Plato and Greene, there is no such thing as human access to brute reality that is unmediated by some human, and therefore flawed, idea of the world.

\section{Notes}

1. John Dewey, Art as Experience (New York: Minton, 1934), 267.

2. Cf. Charles Bingham and Alexander Sidorkin, "Aesthetics and the Paradox of Educational Relation," Journal of the Philosophy of Education 35, no. 1 (2001): 21-30; Kieran Egan, Imagination in Teaching and Learning: Ages 8 to 15 (London: Routledge, 1992); Elliot W. Eisner, The Educational Imagination: On the Design and Evaluation of School Programs (New York: Macmillan, 1979).

3. Cf. John Baldacchino, Education Beyond Education: Self and the Imaginary in Maxine Greene's Philosophy (New York: Peter Lang, 2009); Shaireen Rasheed, “The Existential Concept of Freedom for Maxine Greene: The Influence of Sartre and Merleau-Ponty on Greene's Educational Pedagogy," in Philosophy of Education 2002 (Urbana, IL: Philosophy of Education Society), 394-401; Teresa Wilson, "Maxine's Table: Connecting Action With Imagination in the Thought of Maxine Greene and Hannah Arendt," Educational Theory 53, no. 2 (2003): 203-20.

4. Maxine Greene, Releasing the Imagination: Essays on Education, the Arts, and Social Change (San Francisco:

Jossey-Bass, 1995), 2.

5. Maxine Greene, The Dialectic of Freedom (New York: Teachers College Press, 1988), 126.

6. Greene, Releasing the Imagination, 1.

7. Jean-Paul Sartre, Being and Nothingness: An Essay on Phenomenological Ontology (New York: Philosophical Library, 1956), 434-35, quoted in Greene, Releasing the Imagination, 5.

8. Greene, Releasing the Imagination, 14, 5.

9. John Caputo, More Radical Hermeneutics: On Not Knowing Who We Are (Bloomington: Indiana University Press, 2000), 59, quoted in Claudia Ruitenberg, "Learning to Live with Art," in Philosophy of Education 2002 (Urbana, IL: Philosophy of Education Society, 2002), 452.

10. Ruitenberg, "Learning to Live with Art," 452.

11. Greene, Releasing the Imagination, 16.

12. Mary Warnock, Imagination (Berkeley: University of California Press, 1976), 207, quoted in Greene, Releasing the Imagination, 35.

13. Gary Brent Madison, The Hermeneutics of Postmodernity: Figures and Themes (Bloomington: Indiana University Press, 1988), 91, quoted in Greene, Releasing the Imagination, 38 .

14. All Stephanus numbers in this essay refer to Plato, Collected Dialogues, eds. Edith Hamilton and Huntington Cairns (Princeton: Princeton University Press, 2005). 
15. Jacques Lacan, Écrits: A Selection (New York: Norton, 1977), 5.

16. Ibid, 2,1 .

17. Ibid, 4 .

18. Maxine Greene, Landscapes of Learning (New York: Teachers College Press, 1978), 185.

19. Wallace Stevens, "Imagination as Value," in The Necessary Angel (New York: Vintage Books, 1959), 109, quoted in Greene, Landscapes of Learning, 187.

20. Dewey, Art as Experience, 267.

21. Greene, Releasing the Imagination, 4.

\section{BiBLIOGRAPHY}

Baldacchino, John. Education Beyond Education: Self and the Imaginary in Maxine Greene's Philosophy. New York: Peter Lang, 2009.

Bingham, Charles, and Alexander Sidorkin. "Aesthetics and the Paradox of Educational Relation." Journal of the Philosophy of Education 35, no. 1 (2001): 21-30. Bloom, Allan. Love and Friendship. New York: Simon \& Schuster, 1993.

Caputo, John D. More Radical Hermeneutics: On Not Knowing Who We Are. Bloomington: Indiana University Press, 2000.

Combs, Arthur W. A Personal Approach to Teaching: Beliefs That Make a Difference. Boston: Allyn and Bacon, 1982.

Dewey, John. Art as Experience. New York: Minton, Balch, 1934.

Egan, Kieran. Imagination in Teaching and Learning: Ages 8 to 15. London: Routledge, 1992.

Eisner, Elliot W. The Educational Imagination: On the Design and Evaluation of School Programs. New York: Macmillan, 1979.

Greene, Maxine. Landscapes of Learning. New York: Teachers College Press, 1978.

-_- The Dialectic of Freedom. New York: Teachers College Press, 1988.

-_- Releasing the Imagination: Essays on Education, the Arts, and Social Change. San Francisco: Jossey-Bass, 1995.

-_- Variations on a Blue Guitar: The Lincoln Center Institute Lectures on Aesthetic Education. New York: Teachers College Press, 2001.

Lacan, Jacques. Écrits: A Selection. New York: Norton, 1977.

Madison, Gary Brent. The Hermeneutics of Postmodernity: Figures and Themes. Bloomington: Indiana University Press, 1988.

Markham, Mick. "Through The Looking Glass: Reflective Teaching Through a Lacanian Lens." Curriculum Inquiry 29, no. 1 (1999): 55-76.

Plato. Collected Dialogues, eds. Edith Hamilton and Huntington Cairns. Princeton: Princeton University Press, 2005.

Rasheed, S. “The Existential Concept of Freedom for Maxine Greene: The Influence of Sartre and Merleau-Ponty on Greene's Educational Pedagogy." Philosophy of Education (2002): 394-401.

Ruitenberg, C. (2002). "Learning to Live with Art." Philosophy of Education (2002): 452-59. 
Sartre, Jean-Paul. Being and Nothingness: An Essay on Phenomenological Ontology. New York: Philosophical Library, 1956.

Stevens, Wallace. "Imagination as Value." In The Necessary Angel. New York: Vintage Books, 1959.

Warnock, Mary. Imagination. Berkeley: University of California Press, 1976.

Wilson, Teresa. "Maxine's Table: Connecting Action with Imagination in the Thought of Maxine Greene and Hannah Arendt." Educational Theory 53, no. 2 (2003): 203-20.

Wright, M. V. "Narrative Imagination and Taking the Perspective of Others." Studies in Philosophy and Education 21, no. 4-5 (2008): 407-16.

James Stillwaggon is an assistant professor in the Department of Education at Iona College. Email: jstillwaggon@iona.edu 
